\title{
Assessing changes in urban flood vulnerability through mapping land use from historical information
}

\author{
M. Boudou, B. Danière, and M. Lang \\ Irstea, UR HHLY, Hydrology-Hydraulics, 5 rue de la Doua, 69626 Villeurbanne, France \\ Correspondence to: M. Boudou (martin.boudou@gmail.com) \\ Received: 11 May 2015 - Published in Hydrol. Earth Syst. Sci. Discuss.: 23 June 2015 \\ Revised: 30 September 2015 - Accepted: 4 December 2015 - Published: 18 January 2016
}

\begin{abstract}
This paper presents an appraisal of the temporal evolution of flood vulnerability of two French cities, Besançon and Moissac, which were largely impacted by floods in January 1910 and March 1930, respectively. Both flood events figure among the most significant events recorded in France during the 20th century, in terms of certain parameters such as the intensity and severity of the flood and spatial extension of the damage. An analysis of historical sources allows the mapping of land use and occupation within the areas affected by the two floods, both in past and present contexts, providing an insight of the complexity of flood risk evolution at a local scale.
\end{abstract}

\section{Introduction}

Directive 2007/60/EC on the assessment and management of flood risks draws up a new framework for the promotion of historical information. It aims to reduce and manage the risks that floods pose to human health, the environment, cultural heritage and economic activity. The directive requires member states to first carry out a preliminary assessment by 2011 to identify the river basins and then the associated coastal areas which are at risk of flooding. For such zones, subsequent steps would involve drawing up flood risk maps by 2013 and establishing flood risk management plans focused on prevention, protection and preparedness by 2015 . The directive applies to inland waters as well as all coastal waters across the whole territory of the EU. In France, a national historical database (http://bdhi.fr/), based on the inventory of major floods, was produced in 2011 within the framework of the EU Flood Directive (Lang and Coeur, 2014; Lang et al.,
2012) and was made available to the public in 2015. It contains a description of 176 "remarkable" flood events from 1770 to 2011.

A key issue of the Flood Directive is the accurate assessment of flood risk. A commonly accepted definition of flood risk is the combination of a flood hazard and the vulnerability of the assets that are exposed (de Bruijn, 2005; Schanze, 2006; Cardona et al., 2012). Following this definition, the French Government distinguished two main steps for flood risk assessment. A first step consists of mapping the potential flood extent to evaluate the number of infrastructure assets exposed. Starting from this data, a second step consists of determining the exposure and vulnerability of the asset. For this purpose, some indicators have been adopted, according to the potential impacts on human health, economic activity, the environment, and cultural heritage within the potential flood extent. To mention just a few, these indicators include the number of inhabitants affected, the number of single-storey buildings, the number of employed persons, the number of nuclear power stations, and the area of remarkable built heritage. Following this approach, flood risk assessment leads to a contrasted overview of the actual flood risk. The results indicate a strong and unequal exposure of assets over the French territory and raise some concerns in a context of increasing flood damage (SwissRe, 2015) and global change.

The term "vulnerability" has long been a subject of debate in the scientific literature, being covered by several definitions (Birkmann, 2006; Wisner et al., 1994). A commonly used definition of vulnerability is the likelihood of the elements at risk to produce damage. Based on that definition, assessing the vulnerability and its evolution can be broken down into two main steps: firstly, appraising the exposure by 
listing the elements at risk and, secondly, by evaluating the susceptibility of the elements at risk (Merz et al., 2007). To carry out these two steps, we identify a series of indicators adapted for a retrospective analysis.

On the one hand, the exposure analysis is supported by quantifying the number of buildings and inhabitants at risk. On the other hand, the susceptibility analysis is based on identifying the building use type, providing some keys for understanding the kind of damage to be expected during floods (Barroca et al., 2006). For example, some building types are especially likely to trigger major damage (industrial or commercial activities) or cause disturbances for society (e.g. public infrastructures such as hospitals or schools), thus requiring special attention from risk managers (Merz et al., 2007).

Many authors have already highlighted the importance of historical data as a tool for risk assessment (Glade et al., 2001; Brazdil et al., 2006; Coeur and Lang, 2008; Kjeldsen et al., 2014). A general survey of flood mapping techniques in Europe by de Moel et al. (2009) provides evidence that flood maps are available in almost all countries, based on historical floods or design-basis floods. As an example, Barnikel (2004), Tropeano and Turconi (2004), and Luino et al. (2012) reported past flood extents in relation to presentday land use, which allows developing the prospective analysis of flood risk.

Assessing flood impacts and understanding the past vulnerability of a territory is an essential step towards a longterm mitigation strategy (Changnon et al., 2000). Firstly, it allows for a better understanding of the circumstances that lead to a disaster. Secondly, it helps to shed light on the actual state of vulnerability within a territory. This vulnerability (especially visible through the exposure of assets) should be seen as the result of a complex historical evolution, partly related to the occurrence of damaging flood events in the past (Barrera et al., 2006).

To take account of a potential increase in flood risk, the Flood Directive assessment has to be considered in terms of a long timescale. The indicators developed during the preliminary phase are in fact closely correlated with the present-day situation and raise some questions about the past situation of vulnerability. How do we assess the vulnerability and exposure situations for past flood events based on uncertain and sparse historical sources? Can we validate an increase in the exposure and vulnerability of stakeholders based on a temporal analysis of past disasters? Are these disasters still relevant and easily integrated into risk management policies as indicated in the Flood Directive text?

To address these issues, the present study sets out to highlight the importance of historical information by applying a multidisciplinary and mapping approach (Danière, 2014). Our study is based on the set of 176 major floods in France, which offers an opportunity to explore the vulnerability associated with past flood events. We apply this methodology to two case studies selected for their "remarkability": the Jan- uary 1910 flood event (generalized over all the north-east of France) and the March 1930 flood event (concentrated on the Tarn River valley). We focus our analysis on two cities, Besançon and Moissac, which were largely affected by the floods of 1910 and 1930, respectively. After a brief presentation of the two flood events (Sect. 2), we present the methodological framework used for mapping the vulnerability (Sect. 3). This approach is applied to the two case studies (Sect. 4), illustrating the past and present vulnerability situations in the two cities. Finally, some key points are given (Sect. 5) concerning the importance of historical information for assessing vulnerability changes during the 20th century.

\section{Case studies}

\subsection{Selection of two remarkable flood events}

During the inventory work carried out for the Flood Directive in 2011, we selected a total of 176 major floods in France since 1770 (see Lang and Coeur, 2014) based on the following considerations: diversity of flood types, strong flood hazard or spatial extent, and important socio-economic impacts, in addition to reference events used in planning documents (flood mapping area) or last significant flood in living memory. Using a multidisciplinary methodology, we established an evaluation grid based on three main features (Boudou et al., 2015): (1) flood intensity (score between 3.5 and 14) according to several criteria (return period of maximum peak discharge; duration of submersion; dyke breaches or log jams); (2) flood severity (score between 3 and 12), with two main indicators: flood damage (number of fatalities, economic loss) and social, media or political impacts of the event (establishing a new risk policy, calling for international solidarity to face the crisis, etc.); and (3) spatial extent of damage (score between 2 and 8 ). This grid allowed us to rank the 176 major floods (Boudou, 2015). Then, a second level of selection led us to focus on the nine events shown in Fig. 1 (January 1910, March 1930, October 1940, December 1947/January 1948, December 1959, January 1980, November 1999, December 2000/April 2001 and February 2010). These flood events cover all flood typologies (oceanic/snowmelt/Mediterranean floods, storm surges, cyclones, dam breaching) and are considered as some of the most remarkable in accordance with the evaluation grid. Lang et al. (2012) presented the main characteristics of these nine events (except for the 1947-48 flood).

In this study, we investigate the two oldest selected events, which took place in January 1910 and March 1930, focusing on the urban situation in Besançon and Moissac (Fig. 2). The aim is to focus on two cities that have been significantly flooded in the past and to understand how their vulnerability to flooding has changed up to the present day. A detailed inventory of documentary sources for these two events can be found in the Supplement. 

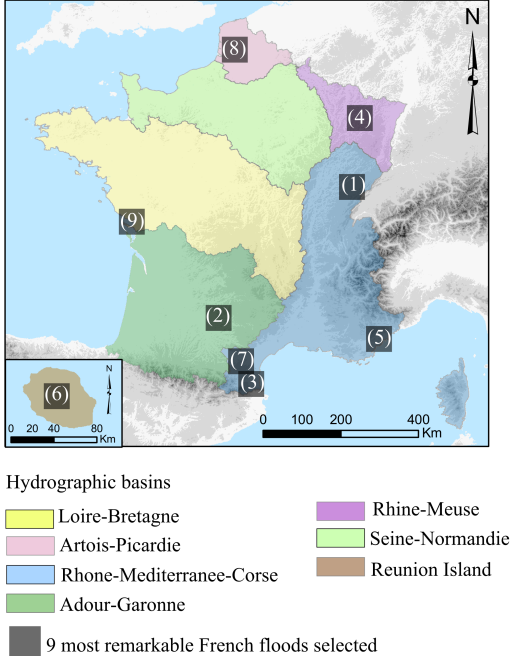

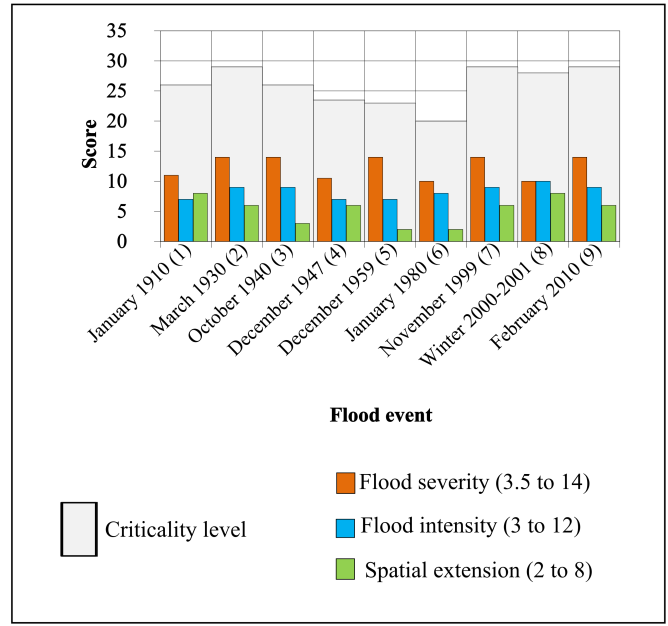

(C) Boudou (2015)

Figure 1. Location map of the nine most remarkable French flood events selected in this study and chart showing their related remarkability scores (Boudou, 2015).

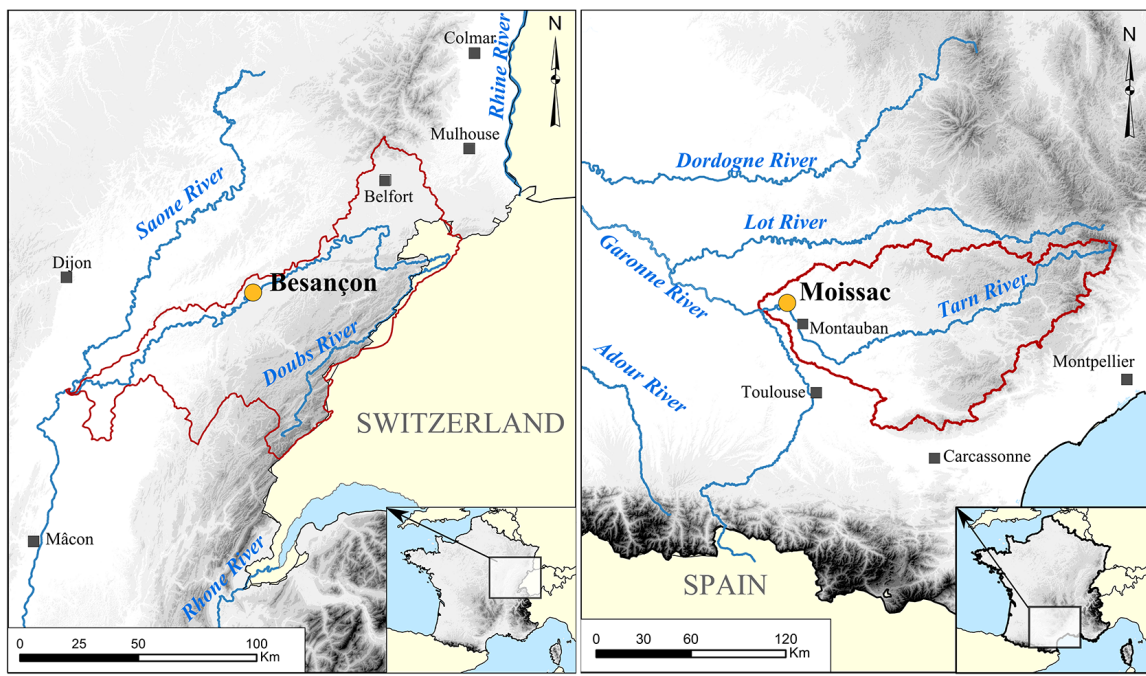

Legend

$\begin{array}{ll}\text { - Main cities } & \text { Case study } \\ \text { - River network } & \square \text { France boundary } \square \text { Catchment studied }\end{array}$

(C) Boudou, Danière (2015)

Figure 2. Location of the case studies: Doubs Basin and Besançon (left panel), Tarn Basin and Moissac (right panel).

\subsection{The January 1910 flood event in Besançon (Doubs River catchment)}

The flood of January 1910 ranks fifth among the nine floods selected as remarkable according to the evaluation grid (Fig. 1). This flood event is mostly known for being the most significant flood affecting the city of Paris, with a return period of about 100 years for several rivers of the Seine Basin. After a very wet end during the year 1909 (450 mm of rainfall in 3 months), the Seine Basin received a large amount of rain and snow in January 1910 (about $300 \mathrm{~mm}$ in the upper part, $110 \mathrm{~mm}$ in the central part, and $280 \mathrm{~mm}$ in the downstream part). The water level at Paris Austerlitz was $8.66 \mathrm{~m}$, the second highest historical level after the flood of February 1658 (8.80 m) (Champion, 1858-1864; Goubet, 1997). There was a relatively small number of direct fatalities (seven deaths) plus nine indirect deaths (collapsing of several cavities), but the impact within the Paris region was extremely high, with 150000 persons affected and economic losses of about FRF 400 million (EUR 1.5 billion, 2015) (Pi- 
card, 1910). Despite the fact that a large part of northern France was also affected, most of the attention of society and recollections of this event have been focused on Paris. To demonstrate the remarkability of this event, not only for the Seine catchment area but also for more rural regions, we concentrate our study on the Doubs Basin where the flood of January 1910 remains one of the most significant historical floods, with the highest water level being recorded in the city of Besançon (see Fig. 3, e.g. $Z=245.55 \mathrm{~m}$ at Poterne, Place la Revolution). While the flood event across the Seine Basin was characterized by a clustering of several oceanic rainfall events, the flood event in the Doubs Basin was triggered by an episode of heavy rainfall from 18 to 21 January (between 150 and $250 \mathrm{~mm}$ ), plus the presence of extensive snow cover after a wet winter which led to significant snow melting. A large part of the old city of Besançon was flooded, with huge damage. Many shops, houses and their basements were inundated, causing important losses of furniture. The streets were also particularly badly affected due to the high flow velocity. In total, the cost of the flooding at Besançon is estimated at around FRF 2 million (DREAL Franche-Comté, 2010), corresponding to EUR 7.7 million in the present day.

According to several documentary sources (Allard, 1910; Ministère de l'Ecologie, 2011), it appears that the hydrometeorological conditions of the event (peak discharge at Besançon of about $1750 \mathrm{~m}^{3} \mathrm{~s}^{-1}$, with a return period of about 100 years; catchment area of $4379 \mathrm{~km}^{2}$ ) cannot explain why the flood level was so high throughout the old city. Such exceptional water levels in the city centre were the consequence of energy losses at the bridges of the town. These energy losses were larger than usual (cf. Fig. 3, in comparison with the 1882 and 1896 flood events) due to a log jam (about $35000 \mathrm{~m}^{3}$ ), resulting from the inundation of a paper factory a few kilometres upstream of Besançon, contributing significantly to a raising of the water level.

Archive sources (especially administrative reports produced by the chief engineer of the Ponts-et-Chaussées, Serial S, Doubs departmental archives) also reveal some major failures of flood warning during the event. Surprised both by the arrival and the intensity of the flood, the local authorities did not succeed in setting up temporary protective structures at the different open city gates ("postern gates"), which directly contributed to the inundation of the city (Fig. 4).

\subsection{The March 1930 flood in Moissac (Tarn River catchment)}

At the end of February 1930, an intense Mediterranean rainfall event occurred in the south-west of France, with hot and moist air from the Mediterranean Sea penetrating deep into the Massif Central highlands. From 25 February to 4 March, a large area was affected by heavy rainfall (e.g. more than $200 \mathrm{~mm}$ over $6000 \mathrm{~km}^{2}$ during 4 days), with a maximum of $694 \mathrm{~mm}$ in 7 days at Saint-Gervais-sur-Mare (spring of the Orb river). The very serious adverse consequences of

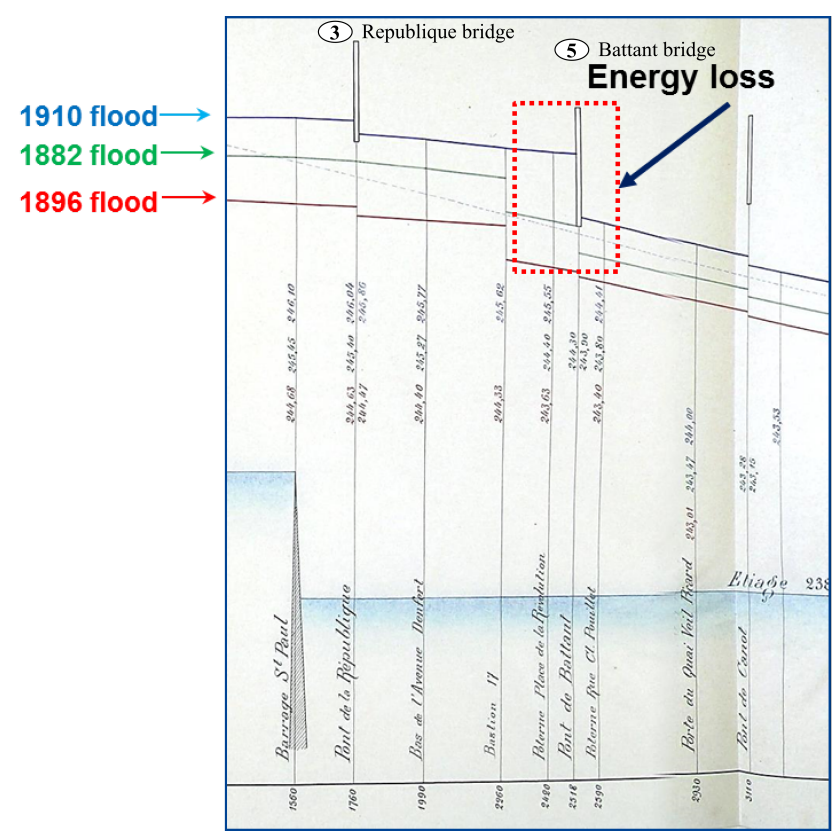

Figure 3. Longitudinal profile of the Doubs River within the old city of Besançon and inter-comparison of floods (sources: Ville de Besançon - Service de la voirie et des eaux: Profil en long des crues du Doubs du 21 janvier 1910, 28 décembre 1882 et 10 mars 1896, 10 mars 1910, Bibliothèque et archives municipales de Besançon, série 0). Locations of the Republique and Battant bridges are shown in Fig. 4.

this rainfall event can be explained by at least two factors. From October 1929 to February 1930, high rainfall totals were observed (e.g. $1177 \mathrm{~mm}$ at Lodève, $840 \mathrm{~mm}$ at Florac), thus favouring a strong reaction of the basins which were already saturated. Moreover, a warming in temperature associated with intense rainfall was causing a large amount of snow melting $(20-100 \mathrm{~cm})$ above $600 \mathrm{~m}$.

Due to its intensity and unusual date of occurrence (at the end of a wet winter) the rainfall event triggered an exceptional flood event (Pardé, 1930). The following flood hazard intensity can be judged exceptional for the downstream part of the Tarn catchment $\left(8000 \mathrm{~m}^{3} \mathrm{~s}^{-1}\right.$ at Moissac, $15400 \mathrm{~km}^{2}$; mean annual discharge $230 \mathrm{~m}^{3} \mathrm{~s}^{-1}$ ), with a return period of about 250-300 years (Dreal Midi-Pyrénées, 2014). Between 210 and 230 fatalities were recorded during this Tarn River flood (resp. Bichambis, 1930, and Boudou, 2015), which represents one of the most destructive flood events ever recorded in France and surely the most significant during the 20th century. The economic loss for the entire surrounding region was estimated at around FRF 1 billion, which corresponds to EUR 570 million in 2015 (Journal Officiel de la République Française, 1930).

One of the striking features of the disaster can be found in the concentration of damage in the town of Moissac (120 deaths out of a total of 210). Reconstructing and mapping the flood chronology using historical sources provides 


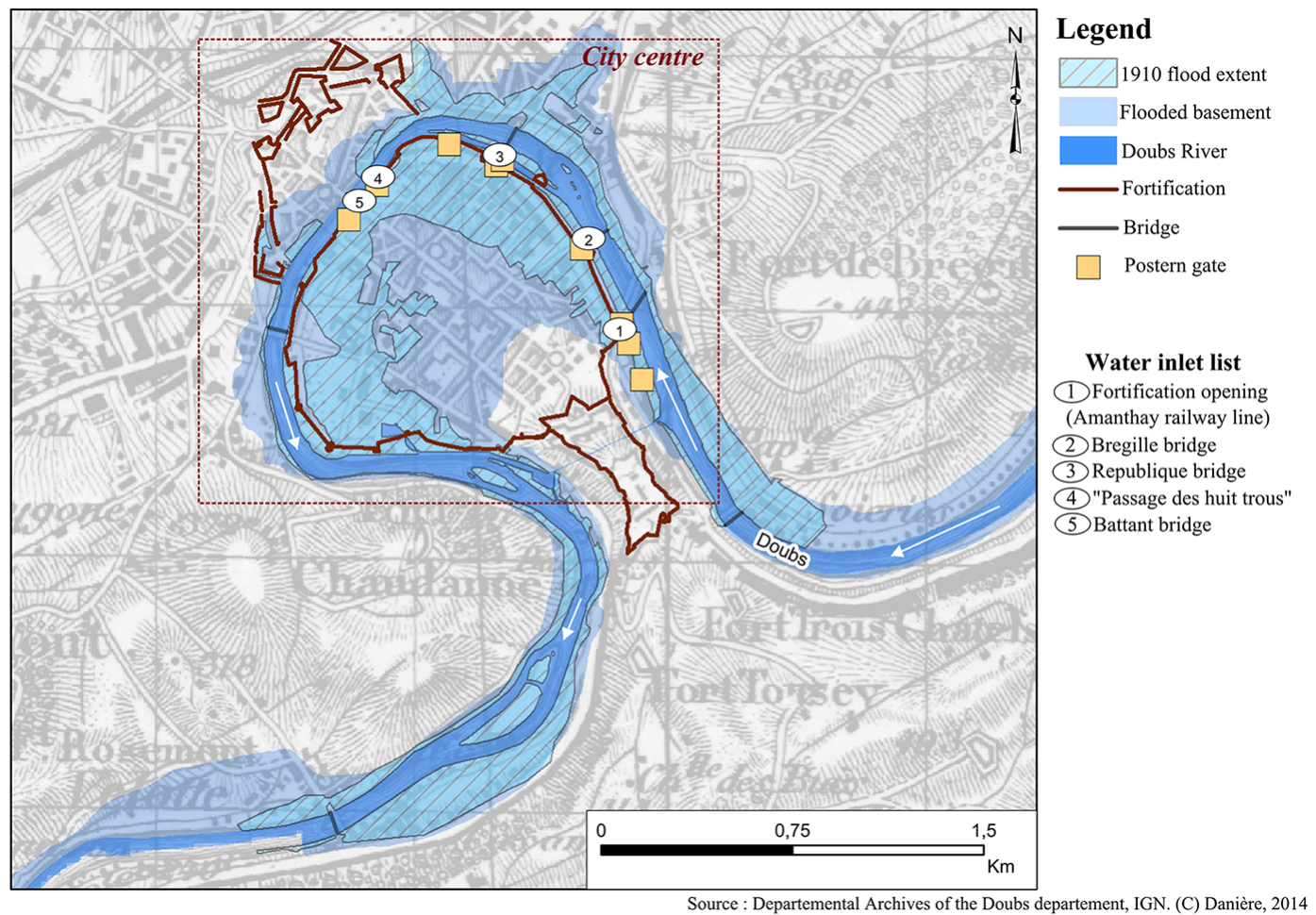

Figure 4. Old Besançon city centre with characteristic water inlets during the flood event on 17-21 February 1910.

us with a better understanding of the circumstances of the disaster (Fig. 5). On 3 March 1930, the flood arrived in the town. Before 18:30 LT (local time) the Tarn River was already overflowing the main channel, on both the south and north banks. Fortunately, the town centre was protected by three main dykes and the railway line embankment. From 18:30 to 23:00 LT, the water level rose and the flood extent covered the area between the main dikes at the eastern part of the town. Around 23:00 LT, at the time of maximum discharge (estimated at around $8000 \mathrm{~m}^{3} \mathrm{~s}^{-1}$ ), three breaches suddenly appeared along the railway embankment. These breaches led to a sudden outburst of the dykes and final inundation of the town.

According to the locations of fatalities and the feedback of information on the disaster, the explanation of the high death toll is twofold. Firstly, the rapid influx of water into the city due to the flash flood and dyke failures induced a surprise effect on the inhabitants of Moissac. Secondly, the collapse of more than 600 houses was related to the typical kind of housing in this region, being built of raw bricks especially vulnerable to flooding and sustained contact with water.

\section{Methodology for monitoring changes in flood vulnerability}

\subsection{Relevance of historical events in the present context?}

One of the main requirements of the Flood Directive is to identify areas with a potential high level of flood risk, based on historical floods that would have significant adverse consequences if they occurred again. As the consequences are dependent on the flood hazard as well as the personal, social and economic assets located in the flood risk zones, one of the main concerns is to assess the changes in local vulnerability of city centres as a function of time. In both case studies, the main casualties and/or economic losses within the catchment were located in a single municipal area. But some aggravating factors are time dependent, such as woody debris upstream of bridges at Besançon or dyke failures to the east of Moissac. Other aggravating factors are related to social vulnerability, such as failure of flood warnings at Besançon or vulnerable building materials at Moissac.

To obtain a better understanding of the local disaster process, our study aims to monitor changes in flood vulnerability, comparing the past and present situations. Several questions have to be addressed. Is it possible to assess correctly the changes in vulnerability over time according to the available sources? Does the mapping of land use provide enough information to identify indicators of vulnerability? Can we 


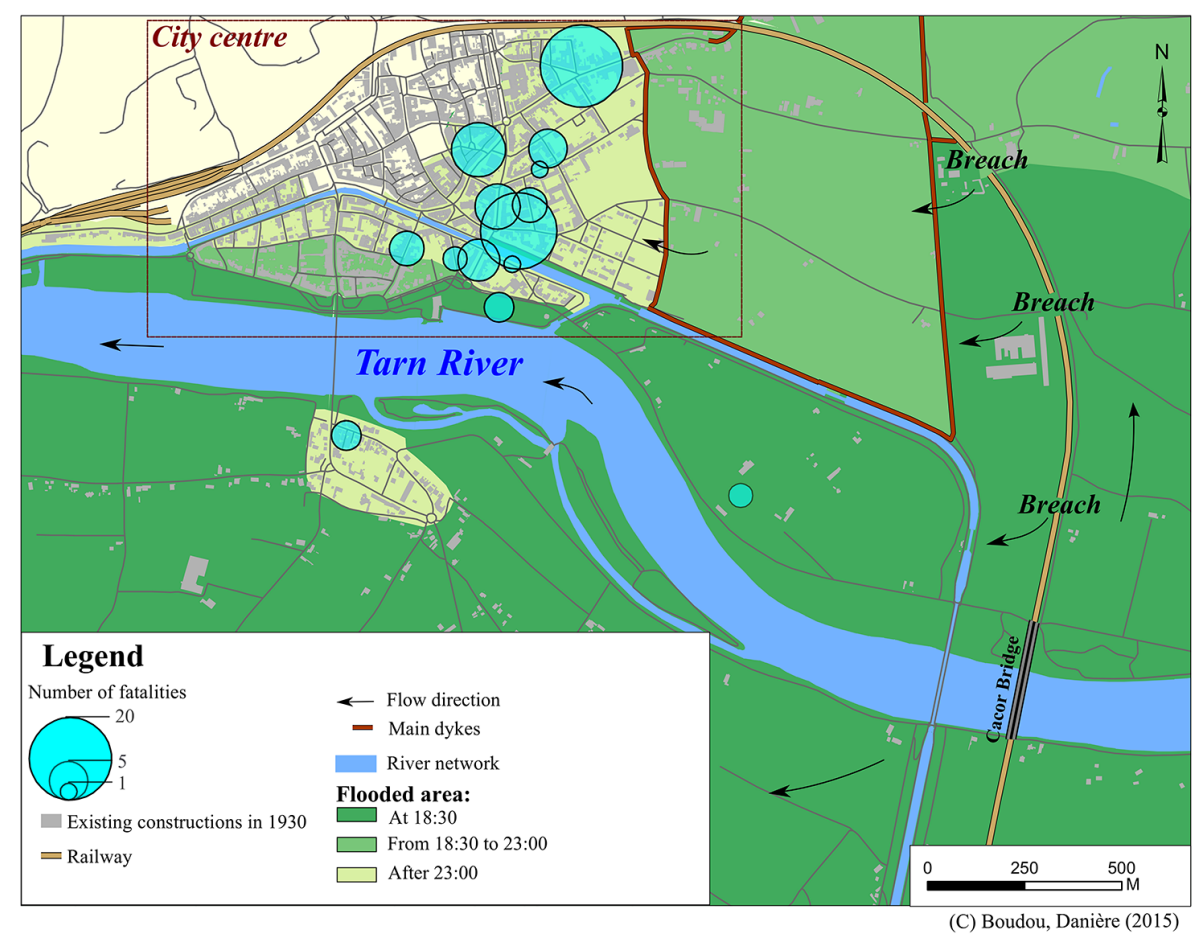

Figure 5. Flood chronology and location of fatalities during the flood event in Moissac on 3 March 1930.

establish scenarios concerning the impact of a future flood based on a historical flood?

After a preliminary analysis that involves georeferencing historical information in the present-day context, we then consider the mapping of land use and estimating the population at risk, while comparing the past and the present situations.

\subsection{Dynamic mapping to locate historical information}

A preliminary step of this study consists of carrying out dynamic mapping with a spatial display of the previously collected historical information. The historical corpus made up of various document formats and sources is included in a GIS by locating the information available. However, some place names have changed since the date of the flood event, thus requiring supplementary treatment of the data.

The dynamic consultation of historical information is not only of interest for correctly locating the various sources of information on flood vulnerability, it can also be used to develop risk awareness and risk culture on an exposed territory. As an example, the high-water mark inventory developed for the Seine River catchment (www.reperesdecrues-seine.fr/ carte.php) provides dynamic mapping which is easily understandable and interactive for the general public, in contrast to the maps resulting from hydraulic or hydromorphogenic modelling (de Moel et al., 2009).

\subsection{Evolution of land use}

In this section, we address the exposure and susceptibility to flood risk (Fig. 6) using simplified descriptors which remain consistent with the level of data availability and accuracy of historical information (Barnikel and Becht, 2003; Barnikel, 2004).

Firstly, the exposure analysis is based on the changes in the population living per building and provides information about the evolution of built-up areas. Secondly, susceptibility analysis based on land-use classification provides relevant information to evaluate the nature of buildings affected during flooding. Historical information is required which at least describes the land cover on different dates. For example, historical maps and aerial photos often depict the built-up territory for a specific year.

To perform a spatial analysis of historical maps, it is necessary to integrate them into a GIS. Three steps are executed: scanning, georeferencing, and digitization supported by a spatial reference system (Fig. 6a) (Rumsey and Williams, 2002; Levin et al., 2010). A set of historical maps and aerial photographs produced by the French National Institute of Geographic and Forest Information (IGN) are used to depict the extent of built-up areas at the scale of a block of houses. A total of seven topographic maps (from 1911 to 1988) are used for Besançon and 26 aerial photographs for Moissac (from 1947 to 1983). Aerial photographs are favoured in the case of Moissac because of the inconvenient representation of the town on topographic maps, which is split between four 


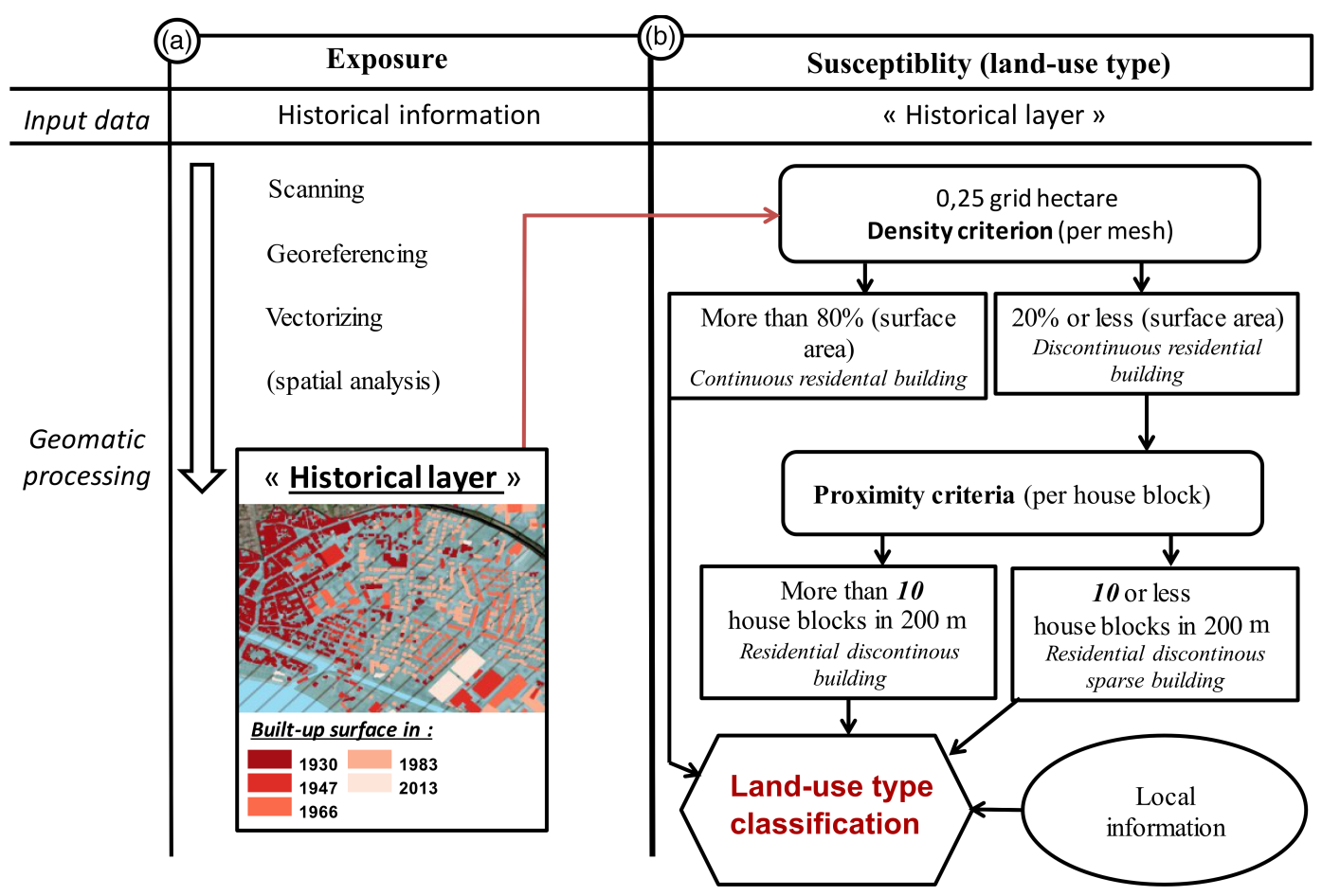

Figure 6. Evolution of vulnerability: (a) exposure and (b) susceptibility (building use type).

map plates. These raster data are then imported and georeferenced. A spatial database (BD TOPO) produced by the IGN, describing the present French territory and its infrastructures, is used to select control points and evaluate distortions during the digitizing step. During this last step, information from topographic maps is vectorized into a unique "historical layer". In this way, each object is given a spatial reality (via the GIS representation) and a temporal reality (by associating a temporal field to indicate its existence for a specific year). Consequently, the "historical layer" allows us to obtain "temporal snapshots" (Langran and Chrisman, 1988; Gregory and Healey, 2007) of the urban fabric: the space is discretized based on information available at the time of the event.

Subsequently, the description of "historical layer" objects provides information on the nature of building exposure. A land-use classification is drawn up based on a nomenclature adapted from the Urban Atlas of the European Environment Agency (http://www.eea.europa.eu/data-and-maps/ data/urban-atlas), according to historical information constraints (Fig. 6b). A first geomatic processing step is performed to discretize the residential buildings on a 0.25 ha grid. A density criterion is applied in each grid cell, based on the percentage contribution to the building footprint, leading to a distinction between dense and sparse areas. To enhance the classification, a second processing step is carried out using a proximity criterion for each building based on the number of buildings within a $200 \mathrm{~m}$ radius (continuous and discontinuous buildings). Local information is then added re- lated to the location and nature of non-residential constructions. BD TOPO data are used to describe the current situation, and a point-in-time layer is built with our "historical corpus" information for earlier historical periods.

\subsection{Census of the exposed population within the flood extent}

General information is provided by the evolution of population at the scale of the municipality. Figure 7 presents the data derived from several population censuses during the 20th century. It shows than the number of inhabitants has grown by about $+100 \%$ at Besançon (from 57978 to 116914 , between 1911 and 2010) and $+60 \%$ at Moissac (from 7814 to 12354 , between 1911 and 2006). As only part of the built-up area was affected by floods, especially in the case of Besançon, it is necessary to cross two layers of information: the number of inhabitants per small block and the spatial extent of the historical flood (1910 or 1930 floods at Besançon and Moissac, respectively).

Human exposure is taken into account by census or an estimation of the resident population. The aim here is to distribute the raw demographic data throughout the blocks of houses by following its evolution at different scales (Wu et al., 2008). The maps so produced can shed light on the evolution of human exposure within the area affected by the flood.

To assess the current population living within the flood extent, we make use of two demographic data sets produced by the French National Institute for Statistics and Economic 


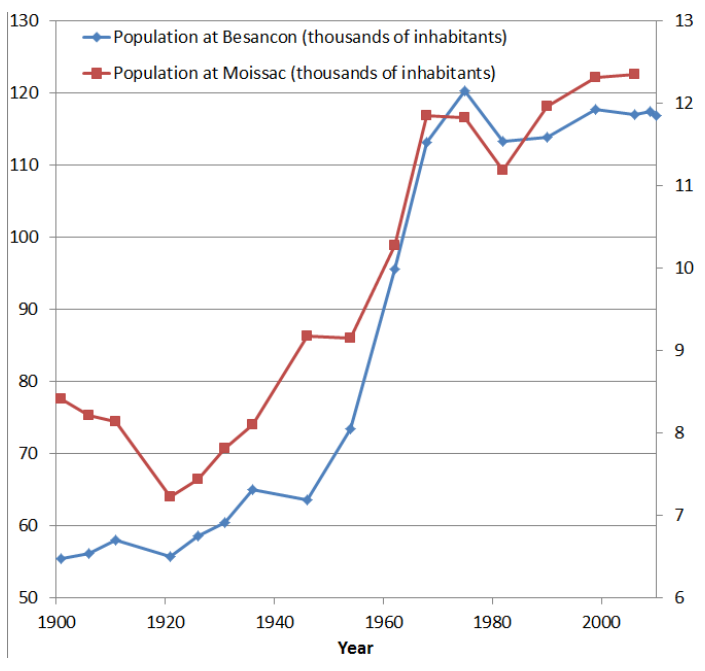

Figure 7. Evolution of the number of inhabitants during the 20th century at Besançon and Moissac. Source: EHESS-Cassini before 1962, INSEE from 1968.

Studies (INSEE), applying Eq. (1) to redistribute the population data at the scale of blocks of houses. The first data set is defined at infra-municipal scale with IRIS (infra-urban statistical area) data. The second data set is based on an estimation of the fiscal population within a $200 \mathrm{~m} \times 200 \mathrm{~m}$ grid. These data sets are distributed at the scale of residential blocks of houses, based on a volumetric method (Lwin and Murayama, 2009), in proportion to the building footprint area multiplied by the vertical density, using the building height provided by BD TOPO:

developed area $=\frac{\text { building height } \times \text { building floor area }}{\text { average storey height }}$.

Historical information, in the form of a census or raw demographic data, is required to estimate (Ekamper, 2010) the numbers of the population exposed at the time of the disaster. General census reports are available for every French municipality (sometimes online), generally compiled every 5 years up until 1946, with some exceptions. These documents contain nominative information about the municipal population, grouped by building and street, at different dates. The comparison between past and present exposed population within the flood extent should take account of possible changes of census methodology over time.

\section{Change of vulnerability based on two case studies}

We now consider the changes of vulnerability in the two case studies, from past to present, using historical sources and current information.
Table 1. Exposed population in 1930 and 2013 for each flooded area (cf. Fig. 11) in Moissac.

\begin{tabular}{lll}
\hline Flooded area (Fig. 11) & 1930 & 2013 \\
\hline$(1)$ & 4089 & 1160 \\
$(2)$ & 1044 & 2880 \\
$(3)$ & 2267 & 2000 \\
\hline Total & 7400 & 6040 \\
\hline
\end{tabular}

\subsection{Changes in vulnerability of Besançon with respect to the January 1910 flood}

Figure 8 displays the land use within the area affected by the 1910 flood in Besançon, based on the situations in 1911 and 2013 (resp. dates of two censuses). No significant change can be seen in terms of vulnerability, according to the spatial extent of the built-up area. Since the centre of Besançon is located within a meander of the Doubs River, with no opportunity for spatial expansion or urban densification, there has been no increase of exposure, apart from the hospital area. Although the city has experienced a spatial expansion towards the north, on the right bank, this area is located outside our zoning at a larger scale.

According to the land-use classification, we can note significant changes in the various activities. There has been a fall in military employment, in favour of an increase in administrative and public facilities. While military areas have decreased by $74 \%$ between 1911 and 2013, administrative areas have grown by a factor of 12 . A reduction of human exposure is noticeable between 1911 (the census year closest to the 1910 flood) and 2013, with a $24 \%$ decrease in the city-centre population.

The demographic evolution is represented on Fig. 9 at the scale of a block of houses, reflecting the decrease in household size (decline in the number of inhabitants per building) and a decline in residential function (reduction of inhabited buildings within the city centre).

\subsection{Changes in vulnerability of Moissac with respect to the March 1930 flood}

The flood risk mapping of Moissac yields an opposite diagnosis, with a major increase of vulnerability within the area affected by the 1930 flood (Fig. 10). Built-up areas have expanded by $122 \%$ between 1930 and 2013. Such spatial extension is explained by new residential development (mainly housing estates) and economic buildings east of the city centre and by a progressive densification of the low-density area on the south bank flood plain.

Despite a new distribution of the population (Table 1), the human exposure has not changed significantly. The reduction of population density in the city centre is compensated by a spatial expansion (Fig. 11). The human expo- 

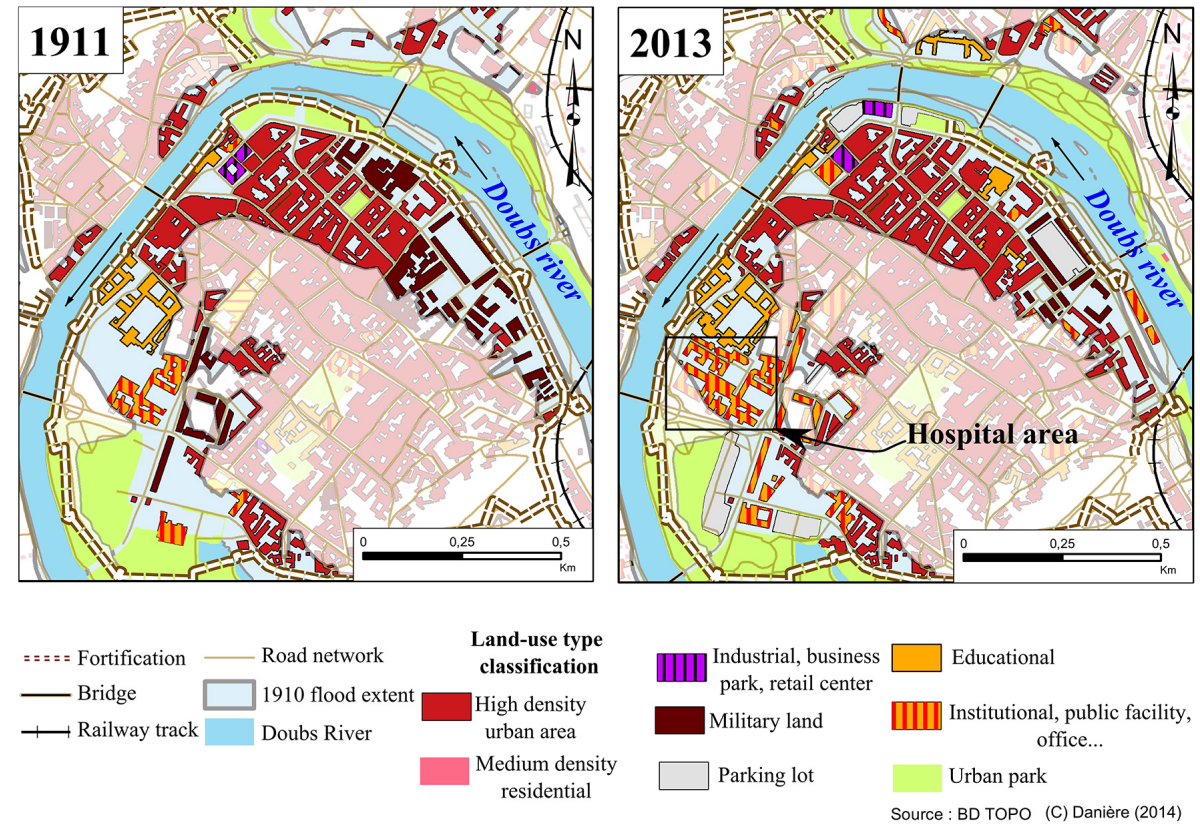

Figure 8. Land-use types and soil occupation within the area affected by the 1910 flood in Besançon: (a) in 1911 and (b) in 2013.
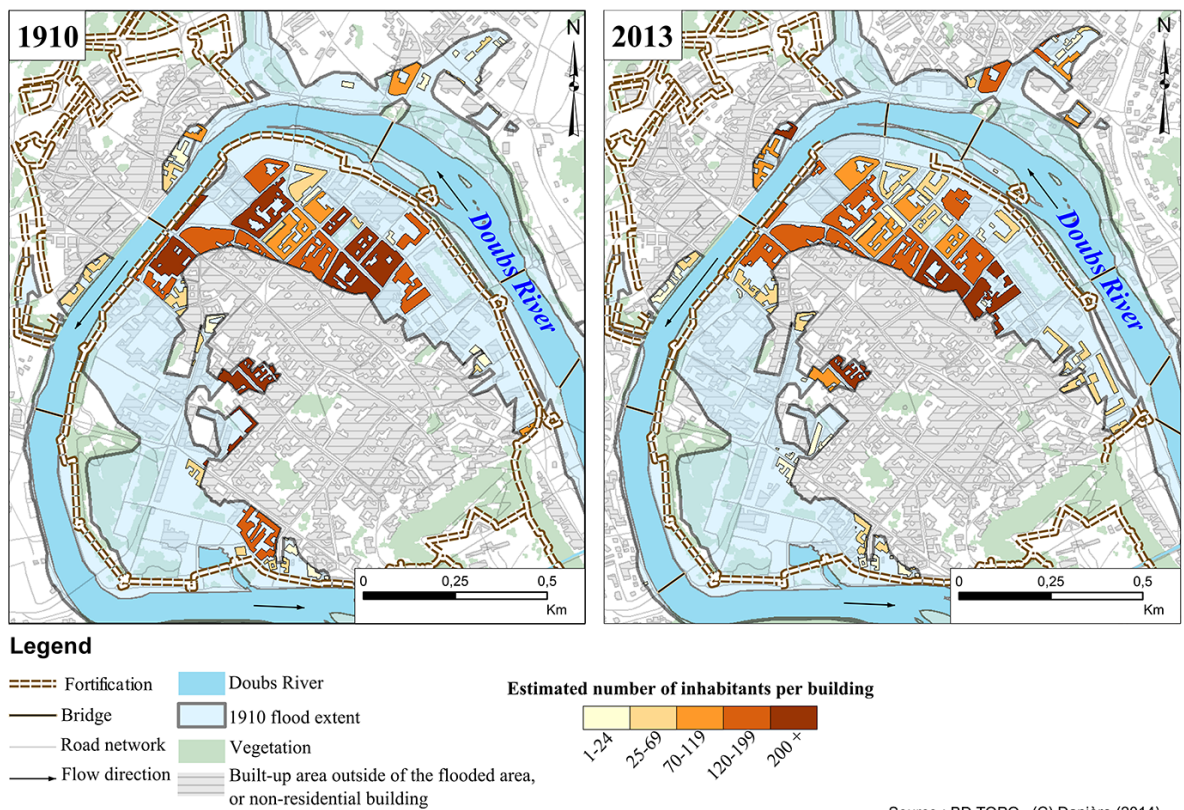

Source : BD TOPO $\quad$ (C) Danière (2014)

Figure 9. Estimated number of inhabitants per building within the area affected by the 1910 flood in Besançon: (a) in 1911 and (b) in 2013. Some blocks of houses are depicted only on one of the maps, because of land-use changes. Non-residential blocks of houses are not taken into account here.

sure has mainly increased on the east side of the city centre, especially in the area located between the two levees. It should be noted that no general census report is available for Moissac in the 1930s. Therefore, the population exposed to flood risk in 1930 was estimated from a raw demographic data set, obtained from an internet database contain- ing a historical population census at the municipality scale (http://cassini.ehess.fr/), which was then distributed according to the volume-based method. 


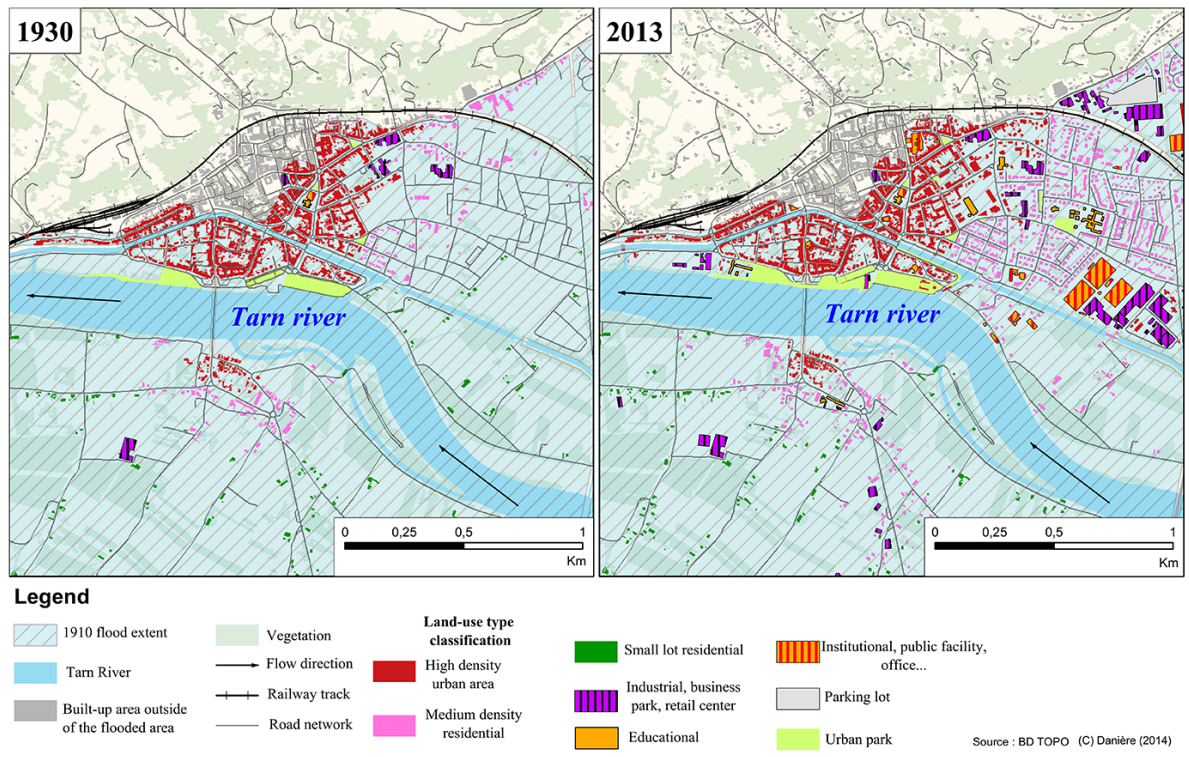

Figure 10. Land-use types and soil occupation within the area affected by the 1930 flood in Moissac: (a) in 1930 and (b) in 2013.
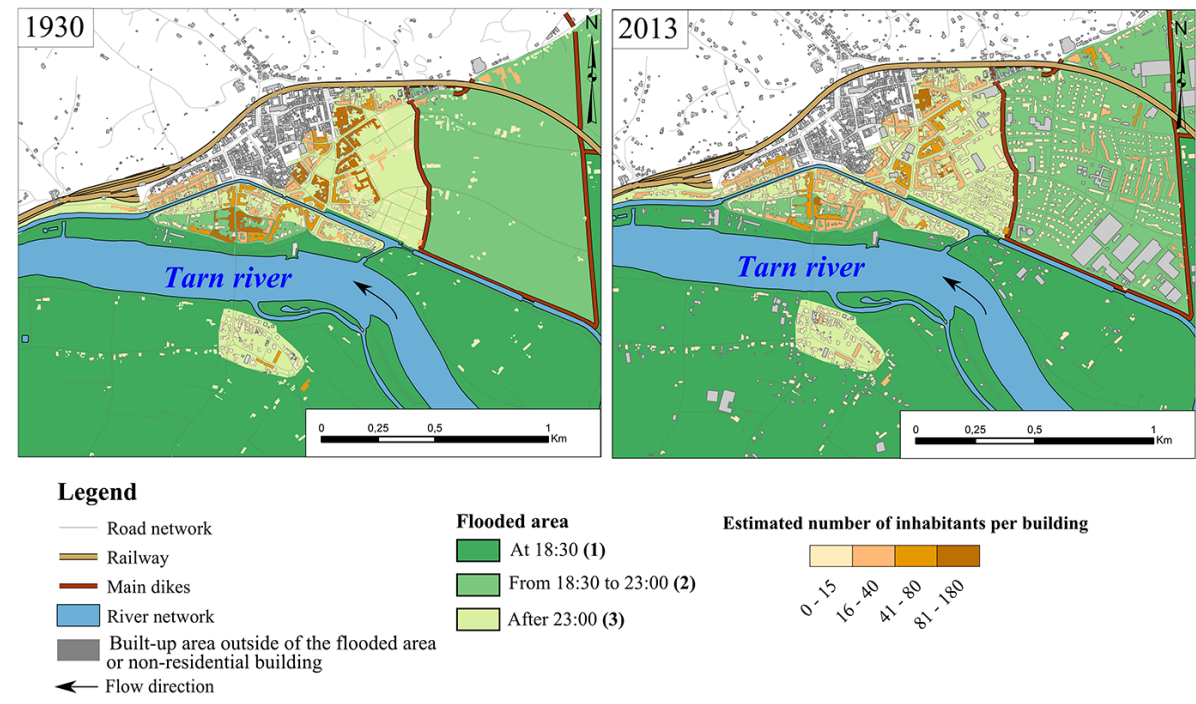

Estimated number of inhabitants per building

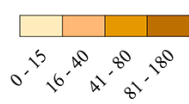

Source : BDTopo IGN, IRIS Data (INSEE) $\quad$ (C) Danière, Boudou (2015)

Figure 11. Estimated number of inhabitants per building within the area affected by the 1930 flood in Moissac: (a) in 1930 and (b) in 2013.

\subsection{Appraisal of the temporal evolution of flood risk}

These two case studies shed light on the complexity of floodrisk evolution. At the nationwide scale, it is clearly acknowledged that the increase of flood damage over the last few decades is induced by a general increase in flood vulnerability (Kron, 2002; Luino et al., 2012; Kundzewicz et al., 2014; Smith et al., 2014). At a local scale, where topographic, social, and economic contexts are crucial, it is necessary to have a more detailed analysis.

In Besançon, there has been no extension of the urban area within the old city since 1910, but significant land-use changes have led to a decrease of flood vulnerability as some previously residential areas are now used as administrative buildings. The frequency of flooding has changed in the historical centre, due to the establishment of safety measures, especially with the construction of mitigation structures such as cofferdams to close the postern gates. Some uncertainties remain for determining the flooded area in the case of an event comparable to the 1910 reference flood, since opposite effects come into play. The log jams at the bridges are not expected to be repeated, but additional hydraulic losses have been introduced by new hydraulic structures since 1910 . 
Nowadays, the reference flood selected in the regulatory documents is a simulated flood larger than the January 1910 flood.

In Moissac, the changes in vulnerability show a more contrasted pattern. As in various other French regions, the built-up areas have grown in spatial extent since 1930, characterized by an important development of housing estates. One critical point is the development of one-storey buildings, leading to a higher human vulnerability due to the lack of a refuge floor. On the other hand, building quality has improved. During the 1930 flood, the house collapses in Moissac and the consequent fatalities were closely related to the construction materials used. To increase the resistance of the structures, new materials and building techniques were used during the reconstruction stage. Another positive change is related to the improvement of safety measures, due to progress in flood-warning decision-making as well as in regards to emergency population evacuation schemes implemented by the civil protection services. The 1930 flood in Moissac, with a return period estimated at around 250 years, is nowadays considered as the reference flood hazard for the local flood risk management strategy as well as for planning and development documents. This territory appears to remain vulnerable, especially to risks of dyke failure.

\section{Conclusion and perspectives}

This paper presents a case study on the urban vulnerability of two French cities that were largely involved in floods occurring in January 1910 and March 1930. This approach gives an insight of the complexity of flood risk evolution, not ignoring the local characteristics. Old maps can provide reliable information on the flood vulnerability in the past, but this requires a necessary evaluation of the modifications occurred in the examined area. A first step is necessary to locate and georeference the historical information within the present geographical reference system. Qualitative information (images, technical reports, national and local newspaper articles, paintings, marble plaques, etc.) can be interpreted as a complement to historical maps on land use. An assessment of the population exposed at risk within spatial units can be inferred from technical documents with nominative lists of people (or inhabitants) as well from old censuses. Historical information on past floods can therefore be useful when building scenarios on future possible floods, providing a reliable reference of what might be possible in terms of water depth, flow velocity and flood extent. Additional work is needed to account for possible changes both in vulnerability and flood hazard over the past several decades (from historical floods to the present day) and for future decades (prospective studies). It is also important to consider the uncertainties associated with historical data and to use relevant scales when mapping vulnerability indicators.
As usual, the temporal analysis of flood risk evolution at a local scale implies a good knowledge of the general context of the socio-economic development of territories, as well as changes in the recollection and perception of risk. According to data availability, this study focuses on a small component of vulnerability only. However, to carry out a comprehensive flood vulnerability analysis, other indicators should be taken into account. After the Xynthia storm surged in 2010 (41 fatalities due to floods in France), Vinet et al. (2012) showed that the age of the population is a key component of local vulnerability. It is clear that the insurance system may benefit from similar analyses on urban flood vulnerability over the last few decades in order to better evaluate the future damages of remarkable floods. Depending on the analysis results, some vulnerability scenarios could be carried out by the risk managers, allowing for the identification of risky areas on which prospective mitigation strategies would be established. Such measures could be realized and financially supported by public authorities, following the example of the experience ALABRI (2012), which led to setting up individual flood protection in the houses preliminarily identified as exposed in the Gard department (http://www.les-gardons.com/alabri/).

This study addresses the issue of flood vulnerability, which is an important component of the flood risk. In parallel, research on flood hazard is also necessary to simulate past floods in a present-day context, taking into account modifications of the river (morphological changes and river engineering) and new settlements on the flood plain.

\section{The Supplement related to this article is available online at doi:10.5194/hess-20-161-2016-supplement.}

Author contributions. M. Boudou established the evaluation grid used for the selection of "remarkable" flood events. He collected data on the two historical floods and produced thematic maps on flood hazard. B. Danière carried out dynamic mapping to locate historical information and thematic maps on flood vulnerability. M. Lang supervised the drafting of the paper.

Acknowledgements. The authors especially thank the DREAL of Besançon, the DDT of Moissac, and the IGN for providing data. We are also grateful to Freddy Vinet and Denis Cœur for their advice. Maria-Carmen Llasat and two anonymous referees are acknowledged for their useful comments. Finally, the authors would like to thank the French Minister of Ecology, Sustainable Development and Energy (MEDDE) for the financial support of Martin Boudou's PhD. Michael Carpenter post-edited the English style and grammar.

Edited by: A. Kiss 


\section{References}

Allard, M.: Les récentes inondations à Besançon, Bibliothèque et archives municipales de la ville de Besançon, Besançon, 1910.

Barnikel, F.: The value of historical documents for hazard zone mapping, Nat. Hazards Earth Syst. Sci., 4, 599-613, doi:10.5194/nhess-4-599-2004, 2004.

Barnikel, F. and Becht, M.: A historical analysis of hazardous events in the Alps - the case of Hindelang (Bavaria, Germany), Nat. Hazards Earth Syst. Sci., 3, 625-635, doi:10.5194/nhess-3-6252003, 2003.

Barrera, A., Llasat, M. C., and Barriendos, M.: Estimation of extreme flash flood evolution in Barcelona County from 1351 to 2005, Nat. Hazards Earth Syst. Sci., 6, 505-518, doi:10.5194/nhess-6-505-2006, 2006.

Barroca, B., Bernardara, P., Mouchel, J. M., and Hubert, G.: Indicators for identification of urban flooding vulnerability, Nat. Hazards Earth Syst. Sci., 6, 553-561, doi:10.5194/nhess-6-5532006, 2006.

Bichambis, P.: Inondations du midi en mars 1930: les paisibles rivières devenues torrents de ruine et de mort. Les deuils, les ruines, les héros, Toulouse, 128 pp., 1930.

Birkmann, J.: Measuring vulnerability to promote disaster-resilient societies: Conceptual frameworks and definitions, in: Measuring vulnerability to natural hazards: Towards disaster resilient societies, United Nations Univ. Press, New York, 9-54, 2006.

Boudou, M.: Approche multidisciplinaire pour la caractérisation d'inondations remarquables: enseignements tirés de de neufs évènements en France (1910-2010), PhD, Univ. Montpellier, Montpellier, 463 pp., 2015.

Boudou, M., Coeur, D., Lang, M., and Vinet, F.: Grille de lecture pour la caractérisation d'événements remarquables d'inondation en France: exemple d'application pour la crue de mars 1930, Environnement, politiques publiques et pratiques locales, Toulouse, 2015.

Brazdil, R., Kundzewicz, Z. W., and Benito, G.: Historical hydrology for studying flood risk in Europe, Hydrolog. Sci. J., 51, 739764, 2006.

Cardona, O. D., Van Alast, M. K., Birkmann, M., Fordham, M., McGregor, G., Perez, R., Pulwarty, R. S., Schipper, E. L. F., and Sinh, B. T.: Determinants of risk: exposure and vulnerability, in: Managing the Risks of Extreme Events and Disasters to Advance Climate Change Adaptation, A Special Report of Working Groups I and II of the Intergovernmental Panel on Climate Change (IPCC), edited by: Field, C. B., Barros, V., Stocker, T. F., Qin, D., Dokken, D. J., Ebi, K. L., Mastrandrea, M. D., Mach, K. J., Plattner, G.-K., Allen, S. K., Tignor, M., andMidgley, P. M., Cambridge University Press, Cambridge, UK, and New York, NY, USA, 65-108, 2012.

Champion, M.: Les inondations en France depuis le VIe siècle jusqu'à nos jours, 6 volumes, Re-édition Cemagref Editions, Paris, 1858-1864.

Changnon, S. A., Pielke, R. A., Changnon, D., Sylves, R. T., and Pulwarty, R.: Human Factors Explain the Increased Losses from Weather and Climate Extremes, B. Am. Meteorol. Soc., 81, 437$442,2000$.

Coeur, D. and Lang, M.: Use of documentary sources on past flood events for flood risk management and land planning, C. R. Geosci., 340, 644-650, 2008.
Danière, B.: Analyse cartographique de l'évolution de la vulnérabilité en zone urbaine face aux inondations dites remarquables, Master 2 Univ. J. Monet Saint-Etienne, Irstea, Lyon, 111 pp., 2014.

de Bruijn, K. M.: Resilience and flood risk management: a systems approach applied to lowland rivers, $\mathrm{PhD}$ dissertation, Delft Univ., Delft, p. 210, 2005.

de Moel, H., van Alphen, J., and Aerts, J. C. J. H.: Flood maps in Europe - methods, availability and use, Nat. Hazards Earth Syst. Sci., 9, 289-301, doi:10.5194/nhess-9-289-2009, 2009.

DREAL Franche-Comté, EPTB Saône-et-Doubs, Ville de Besançon: 1910: la Crue du siècle à Besançon - Dossier de Presse, p. 9, www.franche-comte.developpement-durable.gouv.fr (last access: 1 December 2015), 2010.

Dreal Midi-Pyrénées: Mise en œuvre de la Directive Inondation. Rapport d'accompagnement des cartographies du TRI Montauban Moissac, Toulouse, p. 29+ annexes, 2014.

Ekamper, P.: Using cadastral maps in historical demographic research: Some examples from the Netherlands, Hist. Family, 15, 1-12, 2010.

Glade, T., Albini,, P., and Frances, F.: The use of historical data in natural hazard assessments Advances in Natural and Technological Hazards Research, Kluwer Academic Publishers, Dordrecht, p. 220, 2001.

Goubet, A.: Les crues historiques de la Seine à Paris, La Houille Blanche, 8, 23-27, 1997.

Gregory, I. N. and Healey, R. G.: Historical GIS: structuring, mapping and analysing geographies of the past, Prog. Human Geogr., 31, 638-653, 2007.

Journal Officiel de la République Française: Loi portant création d'un fonds provisionnel d'un milliard de francs, en vue de la réparation des dommages de caractère exceptionnel causés par les orages et les crues du 1er au 30 mars 1930, 88, 3970, Paris, 11 avril 1930.

Kjeldsen, T. R., Macdonald, N., Lang, M., Mediero, L., Albuquerque, T., Bogdanowicz, E., Brazdil, R., Castellarin, A., David, V., Fleig, A., Gül, G. O., Kriauciuniene, J., Kohnova, S., Merz, B., Nicholson, O., Roald, L. A., Salinas, J. L., Sarauskienel, D., Sraj, M., Strupczewski, W., Szolgay, J., Toumazis, A., Vanneuville, W., Veijalainen, N., and Wilson, D.: Documentary evidence of past floods in Europe and their utility in flood frequency estimation, J. Hydrol., 517, 963-973, doi:10.1016/j.jhydrol.2014.06.038, 2014.

Kron, W.: Keynote lecture: Flood risk $=$ hazard $\times$ exposure $\times$ vulnerability, Proceedings of the Flood Defence, Science Press, New York,, 82-97, 2002.

Kundzewicz, Z. W., Kanae, S., Seneviratne, S. I., Handmer, J., Nicholls, N., Peduzzi, P., Mechler, R., Bouwer, L. M., Arnell, N., Mach, K., Muir-Wood, R., Brakenridge, G. R., Kron, W., Benito, G., Honda, Y., Takahashi, K., and Sherstyukov, B.: Flood risk and climate change: global and regional perspectives, Hydrolog. Sci. J., 59, 1-28, 2014.

Lang, M. and Coeur, D., 2014. Les inondations remarquables en France, Inventaire 2011 pour la directive Inondation, Quae, Versailles, p. 640, 2014.

Lang, M., Coeur, C., Bacq, B., Bard, A., Becker, T., Bignon, E., Blanchard, R., Bruckmann, L., Delserieys, M., Edelblutte, C., and Merle, C.: Preliminary Flood Risk Assessment for the European Directive: inventory of French past floods, in: Comprehen- 
sive Flood Risk Management, edited by: Kjlin, F. and Schweckendiek, T., Taylor and Francis group, Rotterdam, 1211-1217, 2012.

Langran, G. and Chrisman, N. R.: A framework for temporal geographic information. Cartographica, Int. J. Geogr. Inf. Geovisual., 25, 1-14, 1988.

Levin, N., Kark, R., and Galilee, E.: Maps and the settlement of southern Palestine, 1799-1948: an historical/GIS analysis, J. Hist. Geogr., 36, 1-18, 2010.

Luino, F., Turconi, L., Petrea, C., and Nigrelli, G.: Uncorrected land-use planning highlighted by flooding: the Alba case study (Piedmont, Italy), Nat. Hazards Earth Syst. Sci., 12, 2329-2346, doi:10.5194/nhess-12-2329-2012, 2012.

Lwin, K. and Murayama, Y.: A GIS Approach to Estimation of Building Population for Micro spatial Analysis, T. GIS, 13, 401414, 2009.

Merz, B., Thieken, A., and Gocht, M.: Flood risk mapping at the local scale: concepts and challenges, in: Flood risk management in Europe, Springer, New York, 231-251, 2007.

Ministère de l'Ecologie: L'évaluation préliminaire des risques d'inondation 2001, Bassin Rhône Méditerranée - Partie III Unité de présentation du Doubs, Lyon, 159-177, 2011.

Pardé, M.: La crue de mars 1930 dans le sud et le sud-ouest de la France: Genèse de la catastrophe, Revue Géographique des Pyrénées et du sud-ouest, 1, 3-99, 1930.

Picard, A.: Rapport de la commission chargée d'analyser les inondations sur le bassin de la Seine de janvier 1910, Rapport au président du Conseil et au ministère de l'Intérieur, Paris, IN, 1910.
Rumsey, D. and Williams, M.: Historical maps in GIS, in: Past time, past place: GIS for history, edited by: Knowles, A. K., ESRI Press, Redlands, CA, 1-18, 2002.

Schanze, J.: Flood risk management - A basic framework, in: Flood Risk Management: Hazards, Vulnerability and Mitigation Measures, Chap. I, Springer, Dordrecht, 1-20, 2006.

Smith, A., Martin, D., and Cockings, S.: Spatio-Temporal Population Modelling for Enhanced Assessment of Urban Exposure to Flood Risk, Appl. Spat. Anal. Policy, 10, 1-19, 2014.

SwissRe: Natural catastrophes and man-made disaster in 2014: convective and winter storms generate most losses, Sigma, 2, 52, 2015.

Tropeano, D. and Turconi, L.: Using Historical Documents for Landslide, Debris Flow and Stream Flood Prevention. Applications in Northern Italy, Nat. Hazards, 31, 663-679, 2004.

Vinet, F., Lumbroso, D., Defossez, S., and Boissier, L.: A comparative analysis of the loss of life during two recent floods in France: the sea surge caused by the storm Xynthia and the flash flood in Var, Nat. Hazards, 61, 1179-1201, 2012.

Wisner, B., Blaikie, P., Cannon, T., and Davis, I: At risk: natural hazards, people's vulnerability and disasters, Routledge, London, p. 284, 1994.

Wu, S. S., Wang, L., and Qiu, X.: Incorporating GIS building data and census housing statistics for sub-block-level population estimation, Profess. Geogr., 60, 121-135, 2008. 